\title{
Evaluation of prospects and barriers of biogas produced from livestock waste towards sustainable development and adaptation to climate change in Nghe An province, Viet Nam
}

\author{
Thu-Nga Do ${ }^{\mathrm{a}}$, Thi-Thoa Le ${ }^{\mathrm{b}}$, Ngoc-Bao Pham $^{\mathrm{c}}$, Duc-Truong Dinh $^{\mathrm{d}}$, Duc-Huu Nguyen $^{\mathrm{a}}$, \\ Wilawan Khanitchaidecha ${ }^{\mathrm{e}}$ \\ a Electric Power University, Hanoi, 11900, Viet Nam \\ ${ }^{\mathrm{b}}$ Deutsche Gesellschaft für Internationale Zusammenarbeit (GIZ) GmbH, Hanoi, 11600, Viet Nam \\ ${ }^{c}$ Institute for Global Environmental Strategies (IGES), Hayama, 240-0115, Japan \\ ${ }^{d}$ National Economics University, Hanoi, 11700, Viet Nam \\ e Naresuan University, Phitsanulok, 65000, Thailand \\ * Corresponding author.Email: dothu_nga20o5@yahoo.com.
}

\section{ABSTRACT}

The livestock sector is one of the fastest growing agricultural subsectors in Viet Nam, resulting in growing demand to sustainably dispose or re-use livestock waste. This research examined the current adoption of biogas digestion of livestock waste treatment at household farms in order to provide insights for policy towards effective implementation. A questionnaire survey was conducted in September 2019, with the participation of 120 livestock owners in Nghe An province, which focussed on accessing their perspectives on biogas and examination of factors impacting their decisions to utilize this technology. Most respondents determined biogas to be an attractive solution for improving the environment. However, several factors limited the development of biogas installation, including technical and financial barriers, awareness and capacity limitations, and financial support as the most significant of these. Government support and policies that encourage household biogas utilization as a sustainable energy source to combat climate change is recommended.

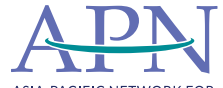

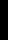




\section{HIGHLIGHTS}

- All respondents were aware of the negative impacts of untreated livestock waste.

- The average volume of household biogas digesters has increased in recent years.

- Large volumes of biogas are wasted due to low quality biogas devices.

Only $35 \%$ of respondents use bio-slurry for crop fertilization.

- Lower livestock prices reduce the demand for biogas installation.

\section{INTRODUCTION}

The livestock sector plays a dominant role in the Vietnamese agriculture industry, accounting for $28 \%$ of agricultural gross value (Tung, 2017) and is one of the fastest growing subsectors. According to the General Statistic Office, Viet Nam's main livestock included 28.15 million pigs, 5.80 million cows and 2.43 million buffaloes by the end of 2018 (GSO, 2020). Further, smallholders contribute significantly to this growth. Approximately $80 \%$ of Viet Nam's pig herds are currently owned by smallholders and this number is expected to remain competitive in the future (Lucila et al., 2012). In 2017, pig production from smallholders contributed $5.5 \%$ to the national GDP (MARD, 2016).

Nghe An, Viet Nam is a typical livestockoriented province, contributing $47 \%$ of the total provincial agricultural production in 2019 (Nghe An GSO, 2019). Provincial reports indicate increasing pressure to handle livestock waste sustainably (Nghe An PC, 2015), with several incidences of water pollution attributed to poor livestock waste disposal. For instance, industrialscale pig farm waste caused severe water quality degradation of the Trang Den Lake in Nam Dan district linked to the Dai Thanh Loc Limited Company (Dac, 2020). Lake water turned black, alongside reports of strong odours from the pollution of pig slurry. Another example from Do Luong district reported damage to 142,000 $\mathrm{m}^{2}$ of rice land, 42,000 $\mathrm{m}^{2}$ of fishponds and contamination of drinking water in 16 households in the commune attributed to the waste effluent from the large-scale pig-breeding farm of Thai Duong Limited Company (Hoan, 2011). Consequently, several solutions have been applied in the province to increase the protection of surrounding environments from untreated livestock waste, including biogas digesters and compost pits. Recovery of biogas from livestock waste is not only a method to obtain a local source of energy but can reduce greenhouse gas (GHG) emissions related to waste management, fossil fuel and chemical fertilizer usage. However, the application of biogas from livestock waste is still limited (Nghe An PC, 2015). The National Energy Master Plan, which aims to prioritize the development of renewable energy sources for electricity production, also stated that the greatest difficulty in developing biogas digestion in Viet Nam is inadequate interest and awareness of livestock farmers and society about the role and benefits of biogas (MOIT, 2017). Additionally, mobilizing people to use a new type of energy is very difficult with routine use of energy from electricity or traditional materials (e.g., coal and/or wood).

Due to its agricultural landscape, Nghe An province was selected as a case study to examine the current situation of adopting biogas digestion for livestock waste treatment in household farms in order to identify challenges, knowledge gaps and insights for policy. To achieve this, a questionnaire survey was conducted to (i) evaluate the biogas potential of the province regarding the reduction of 
GHG emissions and its development as a renewable energy source; (ii) assess household perspectives on using biogas digestion for livestock waste treatment; and (iii) highlight factors that impact household decisions to adopt biogas technology.

\section{METHODOLOGY}

\subsection{Description of the study site}

Nghe An province is located in the North Central Coast of Viet Nam, with an area of $16,490 \mathrm{~km}^{2}$, accounting for $32 \%$ of the total area of the North Central Coast region and $4.98 \%$ of Viet Nam. Landuse is comprised of $75.8 \%$ agricultural land, $7.8 \%$ non-agricultural land and $16.4 \%$ unused land. In 2019, the population was estimated at 3.3 million inhabitants (Nghe An GSO, 2020). The province has 17 districts, 3 towns and a city, stretching from the high mountainous districts of Ky Son, Tuong Duong to delta districts of Dien Chau, Quynh Luu (coastal) (Figure 1).

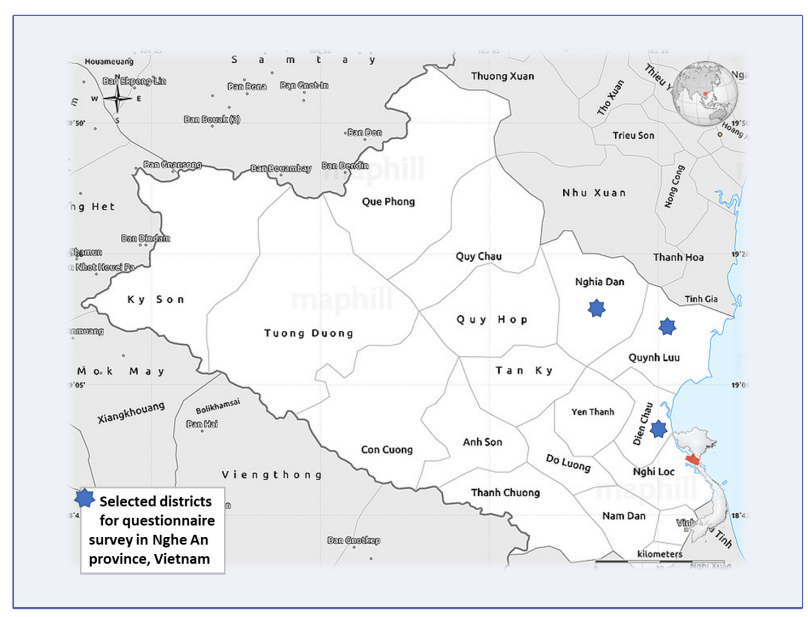

FIGURE 1. Location of the survey in Nghe An province, Viet Nam.

Livestock is an important and growing sector in Nghe An province, with the recent growth rate of livestock numbers estimated to be $5 \%$ to $5.5 \%$ per year. The province has more than 500,000 households producing livestock and poultry (Nghe An GSO, 2019). As of May 2019, total buffalo and cow numbers were estimated at 272,970 and 471,029 heads, respectively. While the total herd of pigs were two-fold higher, at 857,490 heads.

\subsection{Questionnaire survey}

In September 2019, a questionnaire survey was conducted of 120 livestock households from three neighbouring districts of Nghe An province: two delta districts (Dien Chau and Quynh Luu) and one middle mountainous district (Nghia Dan). Trained investigators visited each district and carried out personal interviews with randomly selected households, rather than requesting that respondents complete the surveys on their own. This methodology was chosen on account of the higher accuracy of responses and completion rates compared to the latter. The questionnaire survey focused on the perspectives of households on using biogas digestion for livestock waste treatment and their knowledge on the benefits of biogas technology. Identifying factors that influence household decisions to adopt biogas technology were also included.

\section{RESULTS AND DISCUSSION}

\subsection{Prospects of biogas produced from livestock} waste for GHG reduction and renewable energy

Pig populations in Nghe An province have seen a slight reduction over recent years due to pig disease outbreaks and an increase in the cost of feed and other inputs (Figure 2) (Nghe An PC, 2015). The pig population recovered in 2018 but dropped again in 2019 due to African Swine Fever (Le et al., 2019). The decrease in pig population was 3.4\% annually between 2010 and 2017 but dropped to $17.6 \%$ during the disease outbreak of 2018-2019. Interestingly, the highest number of biogas digesters installed was between 2016 and 2018, as pig numbers increased.

Biogas potential from livestock waste in Nghe An province previously reported by Le, Do, and Dinh (2021) was estimated to emit 3,000 to $5,300 \mathrm{tCO}_{2}$ per year if no waste treatment was applied. These values were estimated using the annual values of pig manure generated in the province $(\sim 2,100-2,900$ thousand tonnes from 2010 to 2019). With the current biogas adoption shown in Figure 2, a reduction of $75 \%$ of emissions could be achieved, equal to 2,200 to $4,000 \mathrm{tCO}_{2}$ per year, and a potential biogas 


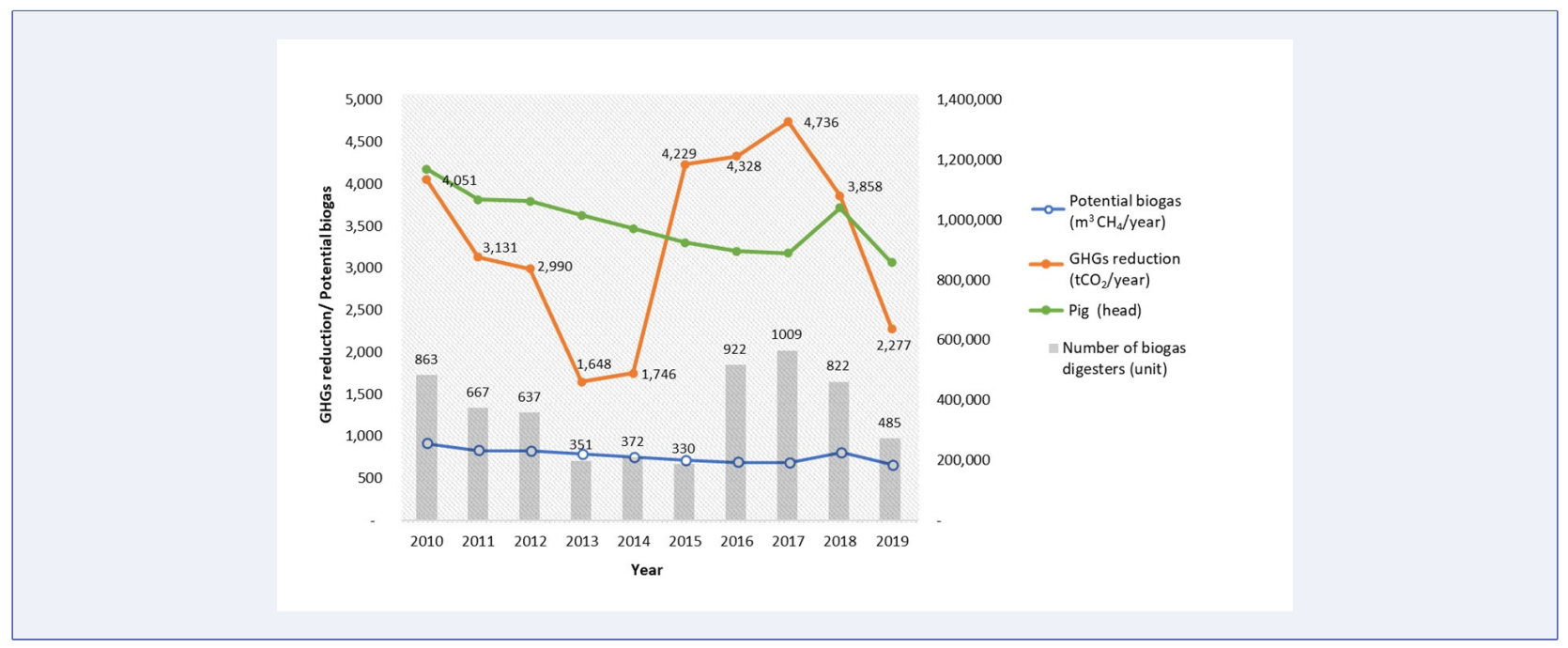

FIGURE 2. Trend of biogas potential and GHG reductions by adopting biogas in Nghe An province from 2010-2019.

load of 700-900 $\mathrm{m}^{3} \mathrm{CH}_{4}$ could be produced (SNV, 2021). Thus, biogas digestion could not only reduce environmental pollution problems but GHG emissions too, via the production of cleaner energy.

\subsection{Status quo of biogas usage in districts of Nghe An province}

In general, pig production in Nghe An province can be divided into industrial and smallholder farms. Industrial farms have at least 20 sows or 100 fatteners, and heavily invest in production, whilst smallholder farms operate on a much smaller scale (i.e., 1-9 heads). In 2015, there were 174 industrial farms located mainly in the delta districts, which jointly kept about $30 \%$ of the total pig herd of the province (Nghe An PC, 2015). The remaining 70\% of the total pig herd belongs to smallholder farms (households), which are more vulnerable to swine diseases due to less hygienic farmyard conditions due to inadequate slurry removal. Biogas utilization could be an effective solution for smallholder farms to cope with this issue.

The delta districts had the highest number of biogas digesters of the different districts, whereas the high mountainous districts had the lowest (Figure 3). The ratio of biogas to pigs in the delta districts was also higher compared to the moutainous districts, which could be due to the higher pig population in the delta districts accounting for $54.5 \%$ of total pig numbers in the whole province (Nghe An
GSO, 2019).

Dien Chau district has the largest number of biogas digesters in the province. This number is two-fold higher than Do Luong and Quynh Luu districts, which have the second largest, with all three located in the delta area. It is important to note that Dien Chau district has not only the biggest amount of biogas, but also the largest ratio of biogas to pig numbers. Even Cua Lo town has one of the largest ratios of biogas to pig number, despite a small number of biogas digesters. Thai Hoa town located in the middle mountainous area, has the second largest ratio of biogas to pig numbers amongst districts in Nghe An province.

\subsection{Questionnaire survey of livestock farmers}

\subsubsection{Characteristics of the livestock households}

The response rate of the questionnaire survey was $100 \%$. In total, the team collected primary data from 120 individuals comprising 78 females and 42 males. This number implies that women are the main labour source in the countryside. An average number of members in a household are between 4 and 5 people, with 2 to 3 people $(82.5 \%)$ accounting for the labour workforce. The ages of respondents ranged between 23 to over 60 years old, with the largest group falling between 31 and 60 years old $(64 \%)$. The educational level of respondents ranged from primary school to high school, with a few possessing undergraduate degrees. More than 


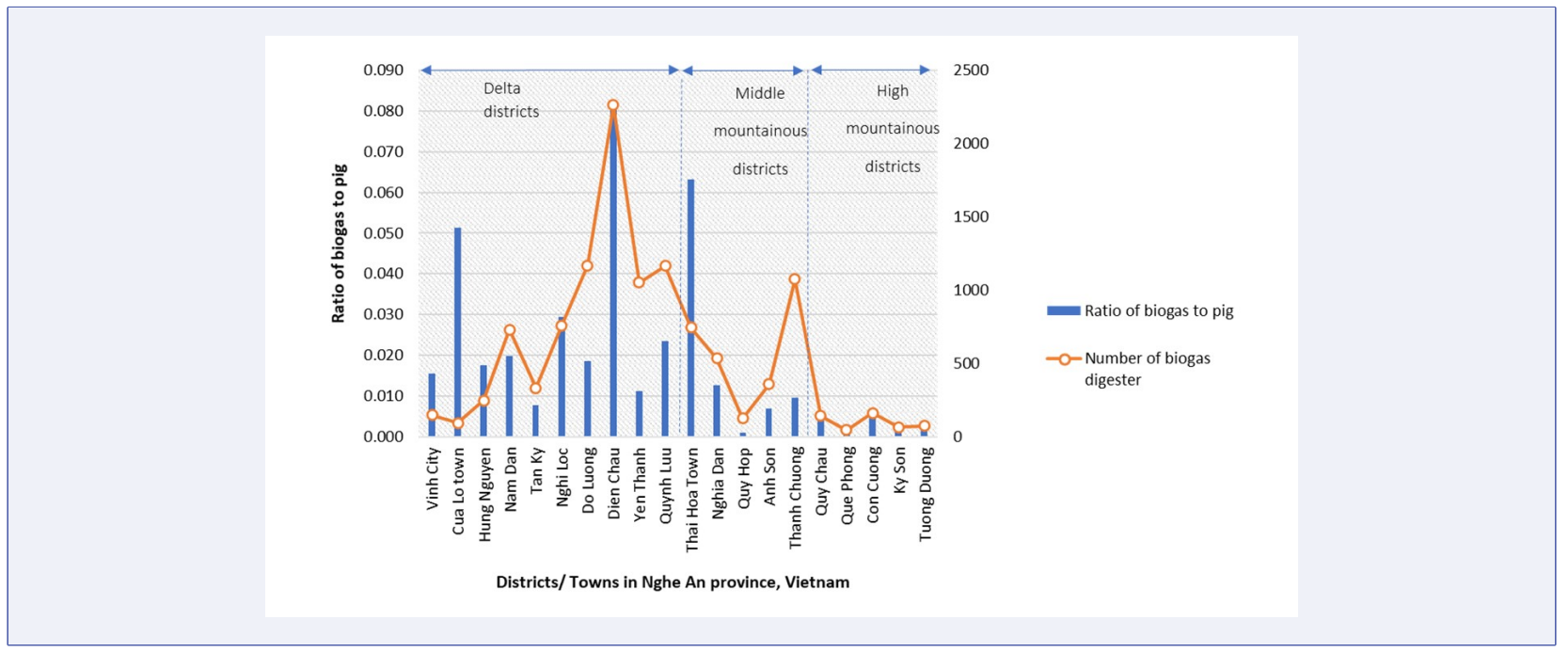

FIGURE 3. Number of biogas digesters (orange line) and the ratio of biogas to pig numbers (blue bars) in various districts of Nghe An province Nghe An GSO (2020).

$10 \%$ of respondents received a primary degree. Survey results indicate the main income from biogas households was from cultivation (35\%), followed by service-trade and business (34\%) and lastly from livestock raising mainly pig production $(31 \%)$. Monthly household income ranges from 2 million to over 10 million VND, with $39 \%$ of respondents earning 2-4 million VND, and 31\% earning 46 million VND. Twenty-eight households had a monthly income of over 6 million VND, and only three of them an income of over 10 million VND.

\subsubsection{General information of the installed biogas digesters}

From 2003 to 2019, $72.5 \%$ of biogas digesters were built in 2014 (Figure 4). The average construction cost per $\mathrm{m}^{3}$ of digestion capacity gradually increased from 884,000 VND in 2003 to $1,407,000$ VND by 2019. This increase was caused by the rise in costs of construction materials and labour. In addition, the selection of biogas digester capacity has to follow the Sectored Standards guideline (MARD, 2006), causing increasing costs of biogas digester capacity. With coverage of $6.9 \mathrm{~m}^{3}$ in 2003, $13.5 \mathrm{~m}^{3}$ in 2015 , then $14.5 \mathrm{~m}^{3}$ in 2019 , this undoubtedly resulted in the steady increase of installation costs per unit.

In contrast, the financial support of 1 million to 1.2 million VND per digester construction from the Government of Viet Nam (GoV) and the
Netherlands Development Organization (SNV) project (SNV, 2021) has not changed over the past few years. Ninety-six point seven percent of the 120 households received financial support but four households (3.3\%) had to pay for the construction cost themselves (about 10-15 million VND). Considering the monthly income of most respondents (from 2-6 million VND), installation is an extravagance. Household decisions to adopt biogas digester installation with no or minimal support stemmed from either complaints regarding livestock waste, and recommendations or experience from other households with biogas digesters as to their benefits.

\subsubsection{Perspectives of households using biogas digestion for livestock waste treatment}

Most respondents determined livestock and domestic waste to be the two main pollution sources in their hometown. They were aware of the negative impacts on human health and living conditions from attending training courses organized by the GoV (MARD, 2016). Most respondents agreed that biogas digestion was a good solution to ensure environmental hygiene when rearing livestock. They experienced benefits such as saving on fuel costs and reducing smoke production from cooking by switching to biogas technology. However, more than half experienced difficulty during operational and maintenance (O\&M) stages. This highlights that 


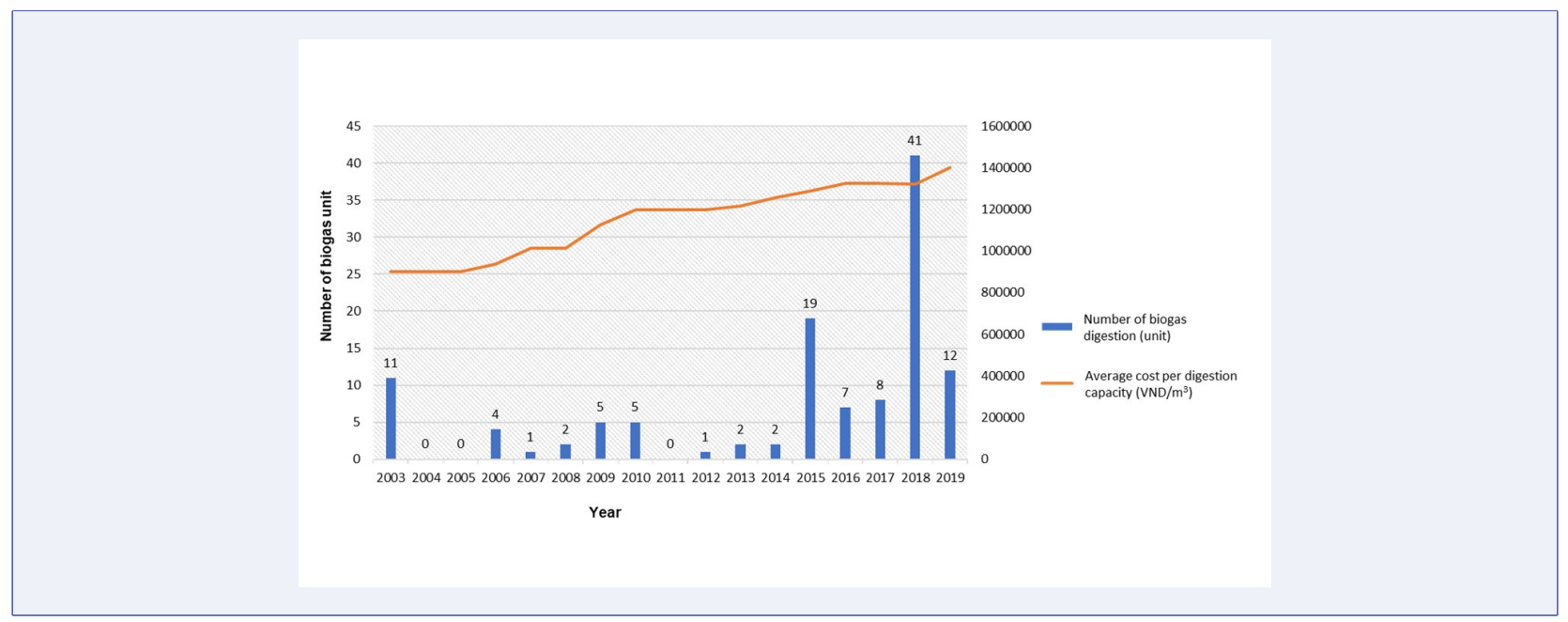

FIGURE 4. Number of biogas and average cost per volume construction.

encouraging farmers to adopt biogas technology requires improvements to follow-up services to ensure the sustainable utilization of this practice. Studies by (Roubík, Mazancova, Banout, \& Verner, 2016) and (Vu, Tran, \& Dang, 2007) reach similar conclusions in other parts of Viet Nam.

Most respondents used biogas for cooking only (95\%), with only a small group using biogas energy for both cooking and lighting ( $5 \%$ ). Typically, most biogas cooking devices are handmade or not brandnamed, with inefficient burning of cooking stoves leading to large volumes of gas wasted. As described in a study in Hue City and Hanoi Capital, Viet Nam, the biggest problem found on farms was the low quality of biogas devices. Gas cookers rusted very quickly and were unusable after 2-4 years ( $\mathrm{Cu}$ et al., 2012).

Seventy-four respondents (61.6\%) supplied surplus biogas (if any) to their neighbours; whereas the remaining $35.8 \%$ burned off excess biogas or released the gas into the atmosphere (2.6\%). It is important to note that respondents expressed their interest in using surplus gas to power electricity generators.

The residue of biogas digestion, bio-slurry, can be used as fertilizer for crop production and aquaculture. Nutrients in bio-slurry, especially nitrogen, are more readily available than in manure, leading to a larger short term fertilization effect. However, only $35 \%$ of respondents use this by-product of biogas digestion for crop fertilization because they have backyard or cultivated land nearby. $65 \%$ of respondents do not use the by-product because they either doubt the benefits (25\%), have no cultivated land $(30 \%)$ or have difficulty in transporting liquid biogas slurries $(10 \%)$. Similar findings reported that $33 \%$ of surveyed farmers used solid parts of digestate as fertilizers for rice, and the use of liquid parts was very limited due to long distances between biogas digestions and rice fields (Hynek, Jana, Le, \& Jan, 2018). From the perspective of farmers, a lack of transport vehicles/devices were considered primary barriers of bio-slurry utilization, which was also confirmed in other studies in Viet Nam $(\mathrm{Vu}$, Vu, Jensen, \& Sommer, 2015), Tanzania (Jackson \& Mtengeti, 2005) and Uganda (Bos \& Kombe, 2009).

\subsubsection{Examine the barriers of biogas development and solutions to overcome the issues}

Most households (78\%) declared positive impacts from biogas adoption. The investment cost followed by livestock population were the most important factors influencing the decision of livestock owners to install biogas digesters. Other factors, such as availability of land for biogas digester construction, the type and size of livestock, the benefits in pollution reduction and production of energy also contributed to farmers' decisionmaking, significantly. This statement is also recognized in many rural areas in Viet Nam (Cu et al., 2012) and in Cambodia (Phanthavongs \& Saikia, 2013). Few households admitted that the financial 
contribution from the GoV of 1 million to 1.2 million VND per biogas digester construction was necessary. However, delays in cash delivery and discrepancies between amounts received across different households were reported. Notwithstanding, this financial support is more meaningful to lower income households, contributing significantly in decisions to install biogas digesters. Besides, this amount needs to be increased to match increasing construction costs. Finally, the questionnaire survey suggests that biogas digester development and its application were heavily dependent on prices of livestock products. When prices for products go down, there is a tendency to reduce or halt livestock production, thus, reducing the demand for biogas digester installation.

Barriers encountered in household biogas development include technical, financial, awareness and capacity limitations (Dinh et al., 2021). Technical support is very important for the O\&M stages of biogas digestion ( ADB, 2016). Development of technical assistance will help in ensuring the quality and safety of constructed biogas digesters. Additionally, the GoV should develop testing procedures and standards for biogas technologies to improve their productivity and reliability. Government policies are important in driving changes to farmers behaviour in waste management and for encouraging private investments (DLP-MARD, 2016). For instance, alongside subsidies, the GoV should further use its tax policy to encourage investments in biogas technologies (for example introducing reduced import taxes and partial exemption from valueadded tax of biogas equipment). Training courses for livestock owners should also cover the update of policies and regulations, as well as sharing successful biogas models, and how to overcome technical barriers in order to convince farmers to use upgraded biogas technology (MOIT, 2017). Institutional capacity building should include the dissemination and update of policy measures to maintain transparency and credibility of governance, and targets to increase the sources of financial support for new biogas digester installation, perhaps through attracting new potential domestic investment (ADB, 2016).

\section{CONCLUSION}

In Viet Nam, the livestock sector has grown rapidly in recent years, resulting in challenges to the handling of livestock waste. Encouraging livestock households to construct biogas digestors is one solution to manage livestock waste, whilst reducing GHG emissions, producing renewable energy, and creating by-products that can be used as organic fertilizers. The questionnaire survey in Nghe An province has highlighted limiting factors to the uptake of livestock waste biogas. Addressing these factors are necessary to upgrade and promote biogas utilization as an effective and costly means toward sustainable agricultural production and climate change mitigation.

\section{ACKNOWLEDGEMENT}

We would like to thank the Asia-Pacific Network for Global Change Research (APN) for providing generous funding to support this research. Special thanks to Dr Linda Anne Stevenson, Ms Christmas Uchiyama, Ms Nafesa Ismail and Ms Aiko Seki, who provided detailed guidance throughout the project implementation. We also extend our sincere gratitude to many stakeholders who participated in the project.

\section{REFERENCES}

ADB. (2016). Viet Nam: Energy sector assessment, strategy and road map. Manila, Philippines: Asian Development Bank. Retrieved from https: //www.adb.org/sites/default/files/institutionaldocument/178616/vie-energy-road-map.pdf

Bos, S., \& Kombe, S. (2009). Mission report on design selection of domestic biogas plant for the Uganda Domestic Programme. Retrieved from http://www.snvworld.org/ en/regions/world/publication

Cu, T., Pham, H., Le, T., Nguyen, V., Le, X., Nguyen, X., \& Sven, G. (2012). Manure management practices on biogas and non-biogas pig farms in developing countries-using livestock farms in Vietnam as an example. Journal of Cleaner Production, 27, 64-71. doi:10.1016/j.jclepro.2012.01.006 
Dac, L. (2020). Dân phản đối trại heo gây ô nhiễm, lãnh đạo huyện họp khẩn. Retrieved from https: //plo.vn/thoi-su/dan-phan-doi-trai-heo-gay-onhiem-lanh-dao-huyen-hop-khan-930352.html

Dinh, D.T., Do, T.N., Le, T.T., Pham, N.B., Nguyen, H.D., Trinh, A.D., \& Khanitchaidecha, W. (2021). Utilization of biogas as an untapped renewable energy source for reducing greenhouse gas emission and enhancing energy security in Vietnam. Economics and Policy of Energy and the Environment.

DLP-MARD. (2016). Overview of Vietnam livestock sector development strategy and restructuring plan. The International Workshop Vietnam Livestock Sector in Economic Integration: Experience Sharing- Future Orientation. Hanoi, Vietnam: Department of Livestock Production, Ministry of Agriculture and Rural Development (DLP-MARD).

GSO. (2020). Livestock sector. Vietnam General Statistical Office. Hanoi, Vietnam: General Statistical Office.

Hoan, K. (2011). Trại lợn gây ô nhiễm bị bao vây. Retrieved from https://thanhnien.vn/doi-song/nhip-songdia-phuong/trai-lon-gay-o-nhiem-bi-bao-vay133530.html

Hynek, R., Jana, M., Le, D., \& Jan, B. (2018). Current approach to manure management for small-scale Southeast Asian farmers-Using Vietnamese biogas and non-biogas farms as an example. Renewable Energy, 115, 362-370. doi:10.1016/j.renene.2017.08.068 Jackson, H., \& Mtengeti, E. (2005). Assessment of animal manure production, management and utilization in Southers Highlands of Tanzania. Livestock Research for Rural Development, 10(7). Retrieved from http://www. lrrd.org/lrrd17/10/jack17110.htm

Le, T.T., Do, T.N., \& Dinh, D.T. (2021). An analysis of potential and barriers for application of biogas in pig waste treatment in Vietnam. Vietnam Environment Administration Magazine (VEM), March 2021, 78-83.

Le, V.P., Jeong, D.G., Yoon, S.W., Kwon, H.M., Trinh, T.B., Nguyen, T.L., ... Song, D. (2019). Outbreak of African swine fever. Emerging Infectious Diseases, 25(7), 14331435. doi:10.3201/eid2507.190303

Lucila, A.L., Nguyen, N.T., Steve, S., Nick, M., Clement, T., Nguyen, N.Q., \& Nguyen, D.A. (2012). Smallholder competitiveness: Insights from household pig production systems in Vietnam. International Livestock Research Institute (ILRI). Retrieved from http://www.fao.org/sustainable-food-value-chains/ library/details/en/c/263196/
MARD. (2006). Training material for Biogas technician. Hanoi: Department of Livestock Production, Ministry of Agriculture and Rural Development (DLP-MARD).

MARD. (2016). Real situation and solutions for environmental treatment of livestock production. Hanoi: Ministry of Agriculture and Rural Development (MARD), Vietnam.

MOIT. (2017). National biomass energy utilization and development plan. Hanoi: Ministry of Industry and Trade (MOIT), Vietnam

Nghe An GSO. (2019). Statistical report of economical and social development in Nghe An Province. In Statistic Year Book of Nghe An province. Nghe An: Department of Agriculture and Rural Development of Nghe An province.

Nghe An GSO. (2020). Statistic Year Book of Nghe An province, 2019. Nghe An: Nghe An Province.

Nghe An PC. (2015). Quy hoạch phát triển sản xuất ngành nông nghiệp tỉnh Nghệ An đến năm 2020, tầm nhìn đến năm 2030 [Development planning of agricultural production in Nghe An province to 2020, vision to 2030]. Nghe An, Viet Nam: Nghe An People Committee.

Phanthavongs, S., \& Saikia, U. (2013). Biogas digesters in small pig farming systems in Lao PDR: evidence of an impact. Livestock Research for Rural Development, 25(12). Retrieved from http://www.lrrd.org/lrrd25/12/ phan25216.htm

Roubík, H., Mazancova, J., Banout, J., \& Verner, V. (2016). Addressing problems at small-scale biogas plants: a case study from central Vietnam. Journal of Cleaner Production, 112, 2784-2792. doi:10.1016/j.jclepro.2015.09.114

SNV. (2021). Over 700.000 gold standard carbon credits issued for Vietnam Biogas Programme. Retrieved from https://snv.org/update/over-700000-goldstandard-carbon-credits-issued-vietnam-biogasprogramme

Tung, D.X. (2017). An overview of agricultural pollution in Vietnam: The livestock sector. New York: World Bank. Retrieved from https://openknowledge. worldbank.org/handle/10986/29244

Vu, T., Vu, D., Jensen, L., \& Sommer, S. (2015). Life cycle assessment of biogas production in smallscale household digesters in Vietnam. AsianAustralasian Journal of Animal Sciences, 28, 716-729. doi:10.5713/ajas.14.0683

Vu, T.K.V., Tran, M.T., \& Dang, T.T.S. (2007). A survey of manure management on pig farms in Northern Vietnam. Livestock Science, 112(3), 288-297. doi:10.1016/j.livsci.2007.09.008 